\title{
THE IMPACT OF EMIGRATION ON REAL WAGES IN IRELAND, $1850-1914$
}

\author{
George R. Boyer, Timothy J. Hatton \\ and Kevin O'Rourke
}

\section{N T R O D U C T I O N}

Ireland's post-famine economic history presents an unusual picture. Largely as a result of mass emigration the Irish population fell to little over half its prefamine level by 1914. Though the proportion of the labor force in agriculture fell, Ireland failed to industrialize as rapidly as other western European countries. Total national income grew slowly although there was a substantial rise in national income per capita.

The effects of mass emigration and falling population on the Irish economy have been debated. Some have seen the mass emigration as depriving Ireland of its brightest and best citizens, reducing Ireland's economic vitality and condemning it to retarded economic development. Others have argued that the emigration itself acted as a vent for surplus population and permitted a growth in per capita incomes and wages which would not have been possible otherwise. In this chapter we argue for the latter view. In terms of the growth rates of real wages, Ireland's performance in the late nineteenth century looks reasonably good by international standards. We maintain that this impressive performance in the absence of rapid industrialization owes much to the decline in the labor force caused by emigration. The key link was the mobility of the Irish population. Integration into the Atlantic labor market meant that the Irish were responsive to relative wage signals. Consequently the large relative wage gap between Ireland and the countries which received Irish immigrants led to mass emigration. The emigration itself tended to relieve pressure on the land and raise Irish wages relative to these receiving countries.

The chapter is organized as follows. First, we examine the growth of Irish wages and living standards in comparison with other countries. Second, we examine the hypothesis that the Irish agricultural wage was responsive to. 


\section{G.R. BOYER, T.J. HATTON AND K. O'ROURKE}

movements in the male population. Third, we attempt to estimate the effect of emigration on the population and labor force of Ireland from 1851-1911. In order to estimate the impact of faster labor force growth, we specify a computable general equilibrium model of the Irish economy. Then the effects of emigration are evaluated in a general equilibrium framework. Finally, we summarize the main findings of the chapter in a short conclusion.

\section{IRISH WAGES AND LIVING STANDARDS, $1850-1914$}

There have been both optimistic and pessimistic views of Ireland's economic progress after the famine. In both cases Ireland's performance is seen as having been closely linked with mass emigration and the fall in population. On the pessimistic side, Joseph Lee has pointed to the slow growth of Irish national income which at about 0.5 percent per annum was the slowest in Europe. He associates this with the failure of industrial development to spread as widely as in other countries (1973: 35). In addition: "Although the average standard of living increased sharply between 1848 and 1877, the actual standard of living rose only slowly. The increase in per capita income reflects the artificial impact of the disappearance of the poorest quarter of the population whose presence had depressed the pre-famine averages without resulting in a remotely comparable increase in the income of the survivors" (1973:12).

Similarly, Fitzpatrick (1984: 37) has argued that: "Emigration from the poorest districts was seldom sufficient to eliminate underemployment; and wage levels for those actually employed rose only slowly and unevenly during the second half of the century."

On the optimistic side Arnold Schrier concluded that:

there can be little doubt that the over-all impact of emigration on the Irish economy was generally favorable. To some extent it relieved the pressure of unemployment and improved the condition of the laborers and tenantry by raising wages and leading to better living accommodations for a larger proportion of the population. It also facilitated the consolidation of small holdings and helped place agriculture on a more economic basis. In addition it made possible a transition in Irish agriculture which can justly be described as revolutionary. Whether in itself it appreciably retarded the development of Irish industry is doubtful since the fiscal and commercial policy of Great Britain operated as a far greater deterrent.

(Schrier 1958: 82)

To some extent differing views of Irish economic performance and the link with emigration can be reconciled. The pessimists would argue that backward agriculture and stunted industrial development drove many Irish men 
and women abroad and the effects of their emigration was simply to mitigate conditions in Ireland.'The optimists would no doubt stress that in the absence of emigration things would have been very much worse. In both cases two key issues are raised. First, how good or bad was the growth in Irish real wages and living standards? Here we suggest that international comparisons can shed additional light on the issue. Second, what would wages and living standards have looked like in the absence of mass emigration? We investigate this issue in later sections of the chapter.

Let us turn to the growth of Irish living standards. Though estimates of Irish national income for the late nineteenth century are somewhat sketchy, Cormac 0 Grada (forthcoming: Ch. 8) has recently suggested that Irish national income per capita rose threefold between 1845 and 1913. While total national income grew at about 0.7 percent per annum, per capita income grew by 1.6 percent. Thus Irish income per capita rose over the period from about two-fifths that of Britain to about three-fifths. He also notes substantial improvements in a number of other measures of well-being. The proportion of the population in poverty declined and the proportion of families living in lower-quality housing (third and fourth class) fell from 63 percent in 1861 to 29 percent 50 years later. Furthermore, increasing prosperity is reflected in the growing commercialization and the increasing variety of consumer goods sold in the shops. The volume of bank deposits increased sharply and small savings, as reflected in post office and trustee savings accounts, grew by a factor of four between 1881 and 1912 .

Though the indicators of GNP per capita and other measures of well-being suggest significant improvement over the period, we can examine labor market conditions more closely through real wage indices, which are more relevant to the labor market situation. Furthermore, they afford direct comparison with other countries, specifically the United States and Britain (the countries to which most Irish emigrants went). ${ }^{1}$ We have constructed wage indices for four occupations, two skilled and two unskilled. The skilled occupations are fitters and carpenters and the unskilled are bricklayers' laborers and agricultural laborers. The construction of these series is discussed in detail in Boyer, Hatton and O'Rourke (1993: Appendix 1).

Using an index for the cost of living we can measure the growth of real wage rates from 1860 on. The striking result is that real agricultural wage rates doubled between 1860 and 1913 with most of the increase occurring before 1895 . From 1860 to 1895 the average annual growth rate was 1.9 percent and for the whole period to 1913 it was 1.6 percent. But it was not only agricultural wages which grew rapidly. Unskilled building wages doubled between 1860 and the early 1890s, exhibiting an annual growth rate of 2.2 percent. Again, wage growth was slower after 1895 and the average growth rate up to 1913 was 1.5 percent. Taking the comparison back to 1850, the data for unskilled building workers reported by Williamson (1994) indicate that between 1850 and 1913 real wage rates increased by a factor 


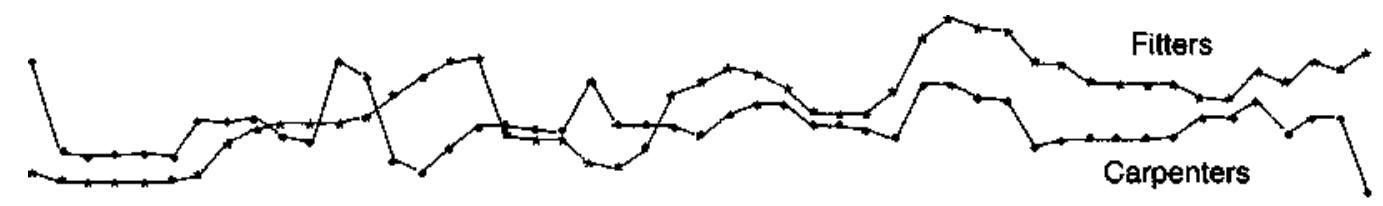

0.90-

0.85-

0.804

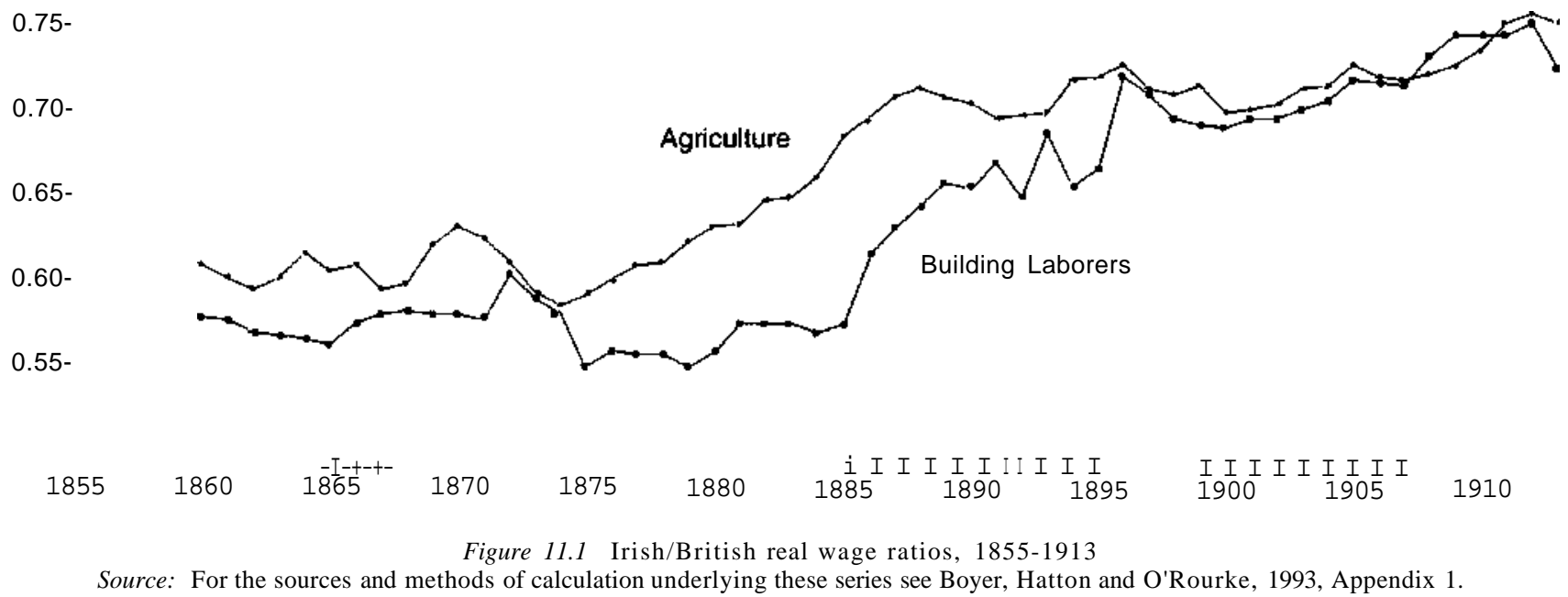




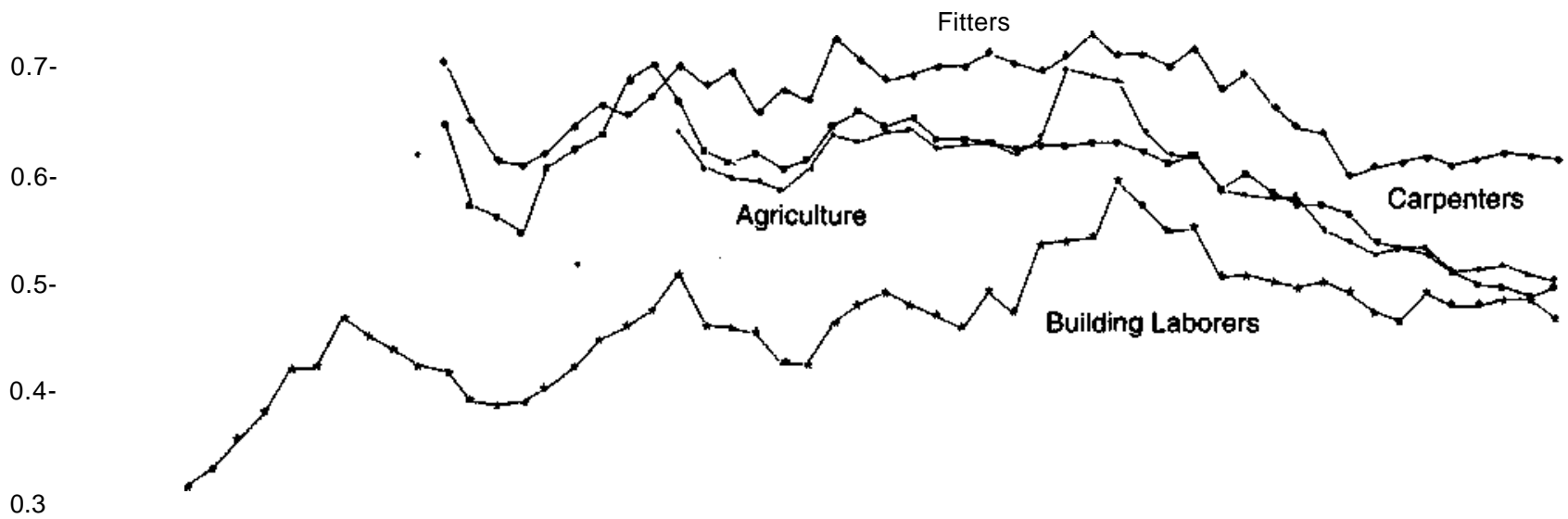


of 2.4, an average growth rate of 1.4 percent per annum.

Our wage series for the skilled trades, carpenters and fitters, begin only in 1866 and exhibit somewhat slower growth than the unskilled wage rates. For carpenters the real wage increased by 56 percent between 1866 and 1895 and, for fitters, 58 percent. The real wage for both groups declined slightly from the mid-1890s to 1913 so that, although both real wages grew by a healthy 1.5 percent annually up to 1895 , they grew by only 0.9 percent per annum over the whole period from 1866 to 1913. Despite the slow growth of all real wages after 1895 and somewhat slower growth of skilled wages, the wage growth for the bulk of workers, the unskilled, was dramatic over the whole period and especially up to the turn of the century. This contrasts sharply with some of the more pessimistic statements about Irish living standards.

In order to compare Irish real wages with those for Britain and the United States, weekly wage rates for each country were adjusted for the absolute difference in price levels between them. The real wage ratios were constructed using methods similar to those used by Williamson (1994) though the individual series used here are different.

Figure 11.1 plots Irish real wages relative to British for the four occupations. For both carpenters and fitters the Irish real wage hovered around 90 percent of the British between 1870 and 1913. The fact that the ratio was so high and the fact that there was so little trend in it suggests that the Irish skilled labor market was closely integrated with the British. What difference remained in real wages might be explained as a compensating differential for the greater attraction to Irish skilled workers of remaining in Ireland rather than moving to Britain. As has often been noted skilled workers in Ireland can be viewed as circulating in the wider labor market for skilled labor in the United Kingdom as a whole. By contrast, both unskilled building and agricultural real wages were much lower in Ireland than in Britain, although they showed a steady advance over time on the British wage. Between 1860 and 1913 the unskilled building wage rose from 58 percent to 72 percent of the British and the agricultural wage rose from 61 to 75 percent of the British.

Because it has not been viewed in international perspective this dramatic growth in unskilled wages has often been neglected in discussions of progress in living standards. The gradual convergence of unskilled wage rates on the British suggests that unskilled labor markets were not as well integrated within the United Kingdom as skilled. But the fact that the Irish/British wage ratios for unskilled building and agriculture were at similar levels during most of the period, and that they advanced at a similar rate in the long run, is suggestive of a closer degree of integration within the unskilled labor market. Relative to Britain at least, these data are consistent with the idea of a gradually declining unskilled labor "surplus" both in rural and urban areas.

Figure 11.2 shows real wage ratios for the four occupations between Ireland and the United States. These present a somewhat mixed picture. In 
the 1860 s they are dominated by the sharp rise in American real wages after the Civil War. Between the early 1870s and the late 1890s, Irish real wages rose relative to American wages for each of the four occupations. But the extent of this increase varied across occupations. It was largest for urban unskilled labor where the Irish/American real wage ratio increased from 0.39 in $1870-3$ to 0.54 in $1896-9$, and lowest for carpenters, where the ratio increased from 0.59 in $1870-3$ to 0.64 in 1893-7. However, from the late 1890s until the outbreak of the First World War the Irish/American wage ratio declined for each occupation. Again, the extent of the decline varied across occupations, being largest for agricultural laborers, where the ratio declined from 0.70 in 1894-6 to 0.50 in 1910-13, and smallest for urban unskilled laborers. Thus it was not until a significant gap in productivity trends opened up between the United States and the United Kingdom in the 1890s that Irish real wages began to grow more slowly than American wages.

In sum, Irish real wages grew faster than British wages between the 1860s and 1913, and faster than American wages between the early 1870s and the late 1890s. This convergence was part of the general trend identified by Williamson (1994) though it was attenuated towards the end of the period. Over the whole period from 1850 to 1913 he finds that Irish unskilled urban real wages rose from 61 to 83 percent of British and from 44 to 54 percent of American (1994: Table A2.1). Given that Ireland did not industrialize rapidly during this period and that its population declined, it is tempting to conclude that the fall in the labor force, by raising the marginal product of labor, particularly in agriculture, underpinned much of the observed real wage growth. This would also be consistent with the rapid growth of unskilled wage rates and a declining rural labor surplus. However, further evidence is needed to support such a conclusion.

\section{GROWTH IN THE AGRICULTURAL REAL WAGE OVER TIME}

Most of the decline in the population and labor force from the famine up to 1913 came in rural areas and in the agricultural sector of the economy. Between 1851 and 1913 the population living in towns of 5,000 or more rose by about 0.5 million; as a proportion of total population it grew from 12 percent in 1851 to 29 percent in 1911. Even more striking is the fact that only two of the 32 Irish counties experienced an increase in population over the period. These were Co. Dublin and Co. Antrim which included the two major Irish cities of Dublin and Belfast; indeed about half of the growth in urban population can be accounted for by Belfast alone.

The consequence of these trends was that the rural population fell by over 2.6 million, almost halving its 1851 level by 1911 . However, due to the decline in population and labor force as a whole, the proportion of occupied males engaged in farming fell only gradually, from 66.3 percent to 54.7 percent 


\section{G.R. BOYER, T.J. HATTON AND K. O'ROURKE}

between 1851 and 1911 (Fitzpatrick 1980: 87). The most severe decline occurred among agricultural laborers. The ratio of farm workers to farmers declined over the period from 2.3 to 1.3 . Hence, farm laborers were becoming an increasingly small minority of the work-force. However, as Fitzpatrick emphasizes, the line between farm laborer and farmer was extremely blurred. Many farm families, particularly on smallholdings, combined work on their own farm with some wage labor. The agricultural wage should therefore accurately reflect the opportunity cost of labor, even where no wage labor was employed directly.

Figure 11.3 plots the weekly agricultural wage divided by an index of the price of farm output. ${ }^{2}$ In relation to the output price, farm wages rose considerably over the period. The rise in the agricultural product wage could be due either to a sustained upward shift in the marginal product of labor due to improved techniques or more capital or because of a movement along the marginal productivity schedule due to the declining labor force. We cannot compare this with the trend in the agricultural labor force or with the labor force as a whole because we lack annual data for these. Instead the graph shows an index of the total male population which declined gradually from 2.9 million to 2.2 million over the period.

One might conclude from the opposite trends in the real wage and male population that this inverse relation reflects a movement along the marginal productivity schedule. However, Irish agriculture underwent substantial change over this period. Most impressive was the shift in the composition of output away from relatively labor-intensive arable production towards relatively land-intensive livestock. ${ }^{3}$ Using a multi-sector computable general equilibrium model of Irish agriculture O'Rourke (1991) has shown that almost all of the decline in the tillage sector between 1856 and 1876 was due to the increasing scarcity of labor. These trends continued later in the century but this was not the only source of rising agricultural productivity. As a number of agricultural historians have shown, there was also steady progress in agricultural techniques. ${ }^{4}$

To what extent can the rise in the product wage be attributed to declining rural population and labor force? As a first step we estimate a dynamic model of the relation between the real wage and male population. In order to account for the short-run fluctuations in labor demand in agriculture we include a variable for the deviation of agricultural output from its logarithmic trend. We include this variable and population lagged one period as well as the lagged dependent variable in order to avoid simultaneous equations bias. The result for the period 1867 to 1913 appears as the first column of Table 11.1.

This equation supports the finding of an inverse relation between the real agricultural wage and population, with a long-run elasticity of-3.2, which is surprisingly large. Two other points should be noted. First, the negative coefficient for the time trend indicates that in the absence of population 


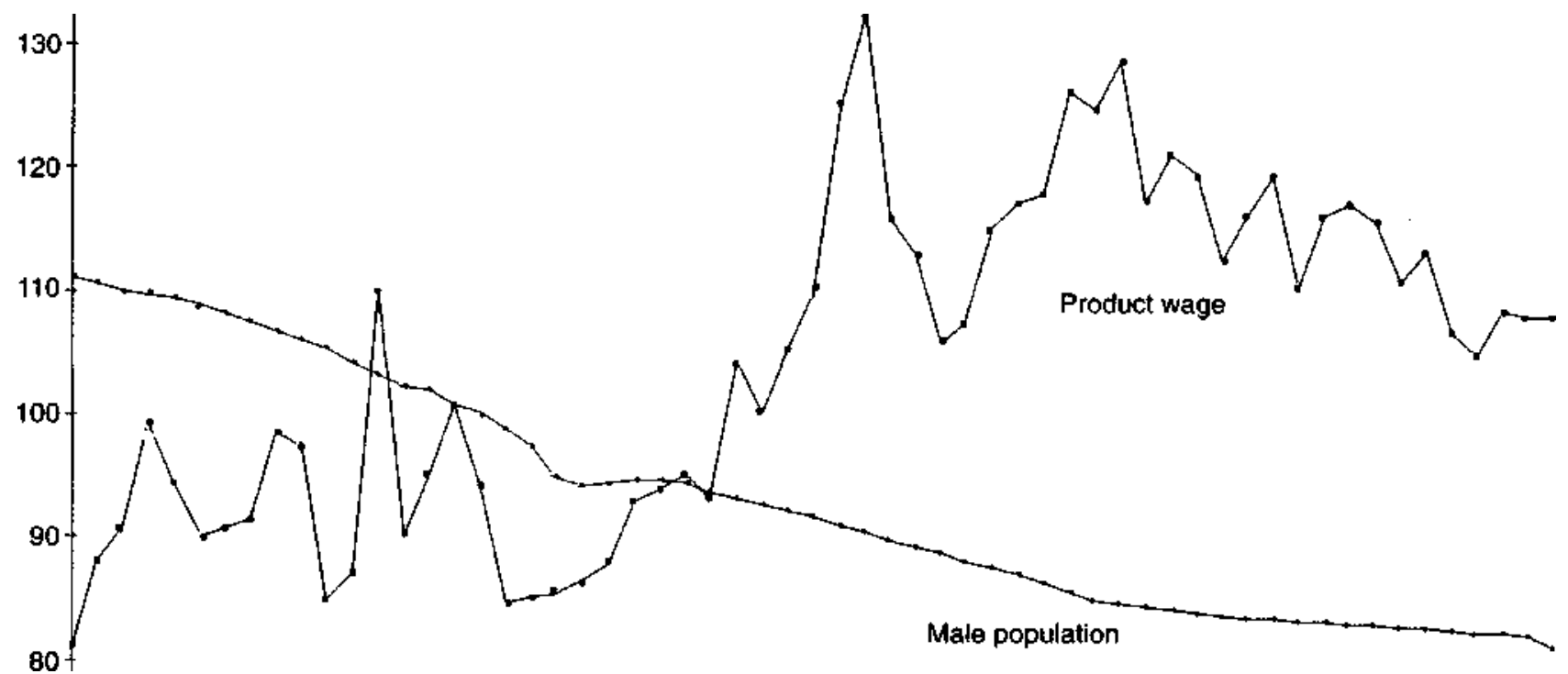

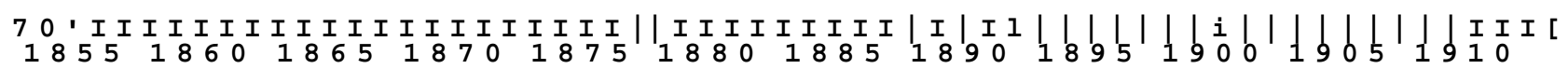

Figure 11.3 Agricultural product wage and male population, Ireland, 1855-1913 $(1870=100)$ Sources: For the product wage, see text; for male population, Mitchell and Deane, 1962, pp. 8-9. 
Table 11.1 Ireland: time-series equations for the agricultural product wage, $1867-1913$

$\begin{array}{lcc} & (O L V & (I V) \\ \text { Constant } & 11.35 & 14.58 \\ & (2.23) & (2.38) \\ \text { Time } & -0.006 & -0.006 \\ & (1.85) & (1.83) \\ \text { Log male population }(t-1) & -1.43 & -1.86 \\ & (2.25) & (2.39) \\ \text { Log product wage }(t-1) & 0.55 & 0.51 \\ \text { Deviation from trend of log } & (4.27) & (3.41) \\ \text { agricultural production }(t-1) & -0.30 & \\ \text { Male emigration rate }(t) & (1.84) & 6.21 \\ & & (1.70) \\ R^{2} & & 0.71 \\ \text { DW } & 0.80 & 0.14 \\ \text { RSS } & 1.79 & 0.14\end{array}$

decline the real wage would have fallen. On the face of it, this would suggest an absence of technical progress and capital accumulation which would normally be expected to raise the real wage. However, population fell more slowly than the labor force in agriculture, hence the time trend may be compensating for the understated decline in the agricultural labor force. Second, the agricultural output term takes a negative sign rather than the positive sign that might have been associated with demand shocks.

The first equation excludes any variable representing the current change in the labor force so the second equation includes the current male emigration rate in place of the agricultural production variable. When this equation was estimated by ordinary least squares the male emigration variable gave a negative and insignificant coefficient. This is not surprising since emigration is found to be inversely related to the Irish wage in the emigration function (see Hatton and Williamson 1993). When instrumental variables are used, the emigration variable gives a positive sign though it is only significant at the 10 percent level. Consistent with its importance in the emigration function, the lagged output variable is used as an instrument for the migration variable.

The point estimate for the emigration rate suggests a large short-run effect of emigration on labor supply which acted to drive up the real wage in agriculture. But this just reflects the current outflow of labor. In the long run the cumulative effect of emigration is still reflected in the declining population. It is worth noting therefore that the lagged population variable remains negative and significant even in the presence of the emigration term. The long-run elasticity is even higher than before at -3.8 . These results are certainly very suggestive of a powerful impact of emigration-driven 
population decline on the real wage in Irish agriculture. However, we cannot be very certain of the rnagnitudes both because the trend in population was different from the trend in the agricultural labor force and because we have not yet studied the long-run impact of emigration on either the population or the labor force.

\section{DEMOGRAPHIC TRENDS AND EMIGRATION}

An appropriate way to examine the effects of emigration on the real wage and other variables over a long period of time is to use a computable general equilibrium model of the economy to consider the counterfactual outcome if there had been no emigration. In order to do this we therefore need an estimate of how the Irish population and labor force would have grown if there had been no emigration from 1851 to 1911 . Such estimates can be little more than controlled conjectures since it is likely that a series of demographic adjustments would have been set in train had there been no emigration. Our objective then is to suggest a range of plausible values rather than to arrive at a definitive estimate.

In 1911 the total stock of Irish-born living abroad was 1.878 million or 30 percent of the total population of Irish-born. Had all the emigrants been living in Ireland the population would have been 6.259 million, a little below the actual population 60 years earlier. A few of these would have been pre1851 emigrants but this number would have been dwarfed by the number of second-generation Irish living abroad. In the United States alone there were 2.141 million of Irish parentage and over a million with one Irish parent though some of these would have been the children of pre-1851 emigrants.

It is likely that the birth rate of the Irish population would have been lower in the absence of emigration. Cormac O Grada (1988: 164) found that in 1911, county level marital fertility rates in Ireland were strongly and positively correlated with previous emigration. This suggests that previous emigrants were partially "replaced" or compensated for. 0 Grada suggests that the rate of replacement was somewhat less than half.

In order to produce a more concrete estimate of the counterfactual Irish population in 1911 we consider a simple demographic model. ${ }^{5}$ Population change from one year to the next depends on the birth rate $(B)$, the death rate (D), and the emigration rate (E). Hence we have:

$$
P_{t}=P_{t \rightarrow},\left(1+B_{t \_x}-D_{t \_x}-E_{t \_x}+2_{t \_x}\right)
$$

where 2 is the residual error. Such errors might be considerable. It has been shown that from the beginning of civil registration in 1864 recorded birth and death rates substantially underestimate the true rates (see Walsh 1970; Coward 1982; O Grada 1991). The degree of under-registration appears to have decreased over time but was still about 3 percent for births and 5 percent for deaths in 1911. $O$ Grada (1975) has shown that emigration to Britain was 


\section{G.R. BOYER, T.J. HATTON AND K. O'ROURKE}

also underenumerated although to a decreasing degree over time.

We can use the relationship above to simulate the Irish population from 1851 eliminating emigration (but leaving in $\mathrm{Z}$ ). ${ }^{6}$ The result of this exercise indicates that the Irish population would have been more than double its actual level in 1911 at 9.773 million and exactly 1.5 times the 1851 level. However, this takes no account of the demographic response to lower emigration. As we have seen there is some evidence that as many as half of the Irish emigrants were "replaced" by increased fertility. An alternative simulation therefore reduces births by half of the emigration rate. The result gives a 1911 population of 6.527 million, close to the actual population level in 1851. These conjectures, though crude, suggest a counterfactual population in 1911 either the same as the 1851 population (low estimate) or one and a half times the 1851 population (high estimate). In terms of growth rates these would be 0.675 percent per year on the high estimate and zero on the low estimate, compared with the actual of -0.661 percent per year. Though these estimates are for the total population growth, it is likely that, over a period as long as 60 years, the labor force effects would be of a similar magnitude. ${ }^{7}$

\section{A GENERAL EQUILIBRIUM MODEL OF THE IRISH ECONOMY，1907-8}

An appropriate way to assess such large-scale effects is through a general equilibrium approach which allows for the full set of interrelationships within the economy. Such methods have been used successfully to estimate the effects of Irish immigration to Britain, 1821-61 (Williamson 1990: Ch. 6), to assess the effects of emigration on Irish agriculture, 1856-76 (O'Rourke 1991), and to evaluate the effects of immigration to the US and emigration from Britain, 1870-1910 (O'Rourke, Williamson and Hatton, Chapter 10). What follows is a summary description of a simple model of the Irish economy in 1907-8, designed to address the issue of the effects of postfamine emigration on Irish living standards. A more detailed description of the model is available in Boyer, Hatton and O'Rourke (1993: Appendix 2).

There are three production sectors in the model: agriculture $(A)$, manufacturing $(M)$, and services (5). The agriculture sector produces food $\left({ }^{\wedge} 4\right)$, using agricultural labor $\left(L_{A}\right)$, capital $(K)$, land $(R)$, and imported manufactures $\left(M_{f}\right.$, representing imported fertilizers). The manufacturing sector produces manufactured goods $(M)$, using non-agricultural labor $\left(L_{N A}\right)$, capital, agricultural goods (food-processing was an important sector in Ireland at the time), imported manufactured goods $\left(M_{F}\right.$, for example, yarns), and "exotic imports" $(F)$, goods for which no domestically produced substitutes are available (for example, raw cotton). Services (5) are produced with non-agricultural labor, capital, and agricultural goods (horses and horse-feed sold to the sector). The production functions can be written: 


$$
\begin{aligned}
A & =A\left(L_{A}, K_{A}, R, M_{F A}\right) \\
' M & =M\left(L_{N A M}, K_{M}, A_{M}, M_{F M}, F_{M}\right) \\
S & =S\left(L_{N A S}, K_{S}, A_{S}\right)
\end{aligned}
$$

All production functions are CES. Elasticities of substitution in manufacturing and services are 0.5, and in agriculture 1.0 (the Cobb-Douglas case). To each production function there corresponds a cost function, which depends only on factor prices due to the assumption of constant returns; competition assures that price equals cost in each sector.

Food and manufactures are internationally traded: Ireland exports domestic manufactures and food, and imports foreign manufactures and exotic imports. Prices of these goods are taken as exogenous, with the exception of domestic manufactured goods prices. As is standard in the literature, Irish manufactured exports face a constant elasticity demand function abroad. Services, by contrast, are non-traded, and their price is endogenously determined.

Agricultural exports are treated as a process whereby a unit of food is transformed into a quantity of "foreign exchange" via a fictitious production function, at a fixed ratio reflecting the exogenous export price. Manufactured exports convert domestic manufactures into foreign exchange via a CobbDouglas production function. Imports convert foreign exchange into import goods through further artificial production functions, again at a constant exogenous ratio reflecting exogenous import prices.

Irish and foreign manufactures are treated as distinct goods. However, they substitute closely with each other in consumption. The representative consumer has a nested utility function: an upper-level Cobb-Douglas utility function defined over food, aggregate manufactures, services and exotic imports (for example tea); and a lower level CES utility function in which Irish and foreign manufactures substitute with each other in the "production" of the aggregate manufactured good, with an elasticity of substitution of 10 .

The consumer is endowed with enough of the numeraire good to allow him to run the (tiny) trade deficit that was observed in 1908. The consumer is also endowed with capital, land, and raw labor $\left(L_{R}\right)$. Land is only used in agriculture. Capital is freely mobile between sectors. The raw labor is transformed into agricultural and non-agricultural labor via a further pseudo-production function:

$$
\left(L_{A}, L_{N A}\right)=L\left(L_{R}\right)
$$

This function is of the constant elasticity of transformation form. The elasticity of transformation reflects the sensitivity of the distribution of labor between town and country to rural-urban wage gaps. This formulation allows labor to be mobile between town and country, while at the same time 


\section{G.R. BOYER, T.J. HATTON AND K. O'ROURKE}

allowing for the existence of persistent (and endogenous) rural-urban wage gaps.

To each sector there corresponds an activity level to be determined; for each sector, price equals cost. (This also holds for the artificial sectors reflecting trade and rural-urban migration. The price-cost equations for the trade sectors tie down the exogenous goods prices.) For each commodity, there is a price to be determined, as well as a demand equals supply equation. The consumer's income (and hence utility) have to be determined; income and expenditure are constrained to be equal. There are thus as many equations in the model as there are unknowns; as usual, Walras's Law implies that one can only solve for relative prices. The "foreign exchange" good, whose only purpose in the model is to facilitate international trade, is taken to be the numeraire. This is analogous to fixing the nominal trade deficit (at its actual insignificant level).

\section{GENERAL EQUILIBRIUM RESULTS}

In order to evaluate the effects of emigration from Ireland in the post-famine era we take our model for 1907-8 and examine the effects of increasing the population and labor force by an amount which reflects the no-emigration counterfactual. We then compare the magnitudes of the model's endogenous variables with the actual values for 1907-8. In the light of our discussion of the demographic impact of emigration we evaluate two alternatives: the low estimate in which population and labor force in 1907-8 are set at their 1851 levels and the high estimate where these are set at one and a half times the 1851 values. We also examine two alternative assumptions about international capital mobility: in the first, capital is completely immobile so that the capital stock in the counterf actual is held at its actual level in 1907-8; in the second, capital is completely mobile at the ruling world interest rate. ${ }^{8}$

The counterfactual values of some of the key variables in the model as a proportion of the actual values in 1907-8 are reported in Table 11.2. Turning first to the results with immobile capital, the two real wage rates (nominal wages divided by the cost of living index) not surprisingly would have been lower in the absence of emigration. The agricultural wage would have been 16 (29) percent lower had the labor force been 49 (123) percent higher. The non-agricultural wage would have been 19-34 percent lower with no emigration. The elasticity of the real agricultural wage with respect to the labor force is between minus a quarter and minus a third. Though these effects are large, they are not nearly as large as the effects of population on the product wage estimated earlier.

The overall change in national income is quite substantial, rising by twothirds in the upper estimate, but per capita income would have fallen by up to 25 percent. Would this have involved a massive shift in the labor force into manufacturing and services? Given our assumption about relatively high 
EMIGRATION \& REAL WAGES IN IRELAND 1850-1914

Table 11.2 Computable general equilibrium analysis, Ireland, 1907-8

\begin{tabular}{|c|c|c|c|c|}
\hline & \multicolumn{2}{|c|}{ Capital immobile } & \multicolumn{2}{|c|}{ Capital mobile } \\
\hline & $\begin{array}{l}\text { Lower } \\
\text { (1) }\end{array}$ & $\begin{array}{l}\text { Upper } \\
\text { (2) }\end{array}$ & $\begin{array}{l}\text { Lower } \\
\text { (3) }\end{array}$ & $\begin{array}{c}\text { Upper } \\
\text { (4) }\end{array}$ \\
\hline \multicolumn{5}{|l|}{ Counterfactual labor force } \\
\hline Agricultural real wage & 0.84 & 0.71 & 0.94 & 0.89 \\
\hline Non-agricultural real wage & 0.81 & 0.66 & 0.94 & 0.89 \\
\hline Gross National Product & 1.29 & 1.66 & 1.42 & 2.02 \\
\hline GNP per capita & 0.87 & 0.75 & 0.95 & 0.91 \\
\hline \multicolumn{5}{|l|}{ Labor force in: } \\
\hline Agriculture & 1.77 & 3.08 & 1.48 & 2.20 \\
\hline Manufacturing & 1.18 & 1.30 & 1.51 & 2.30 \\
\hline Services & 1.37 & 1.88 & 1.47 & 2.17 \\
\hline \multicolumn{5}{|l|}{ Real rental rates: } \\
\hline Land & 1.50 & 2.20 & 1.39 & 1.96 \\
\hline Capital & 1.38 & 1.83 & 1.02 & 1.03 \\
\hline
\end{tabular}

internal labor mobility, the results suggest that a greater proportion of the labor force would have been in agriculture, and the manufacturing labor force would have increased by much less.

The bottom two rows indicate that more labor would have dramatically increased marginal productivity and therefore the real rental rates on both land and capital. However, with internationally mobile capital as in columns 3 and 4 of Table 11.2, the return on capital rises only slightly (because of the fall in consumer prices) but that on land still nearly doubles on the upper estimate. With a substantial capital inflow, the marginal productivity of labor in services and especially manufacturing is higher than otherwise and more labor is shifted into the manufacturing and service sectors. The results suggest that with mobile capital, the share of the labor force in the manufacturing sector would have been slightly higher than the actual share in 1907-8.

The fall in real wages is much attenuated under international capital mobility. Both the agricultural and non-agricultural wage would have declined by a modest 11 percent under the upper estimate, and by only 6 percent under the lower estimate. Gross national product would also have been substantially higher, more than doubling on the upper estimate, and accordingly the decline in per capita income would have been smaller. These results indicate the importance of the capital mobility assumption. Changing other important assumptions appears to have less quantitative impact on the results. ${ }^{9}$

To give a perspective on the results in growth terms, in Table 11.3 we compare actual with counterfactual growth rates of wages and income from 1858 to 1908 . To do this we use the real wage index discussed earlier, using 


\section{G.R. BOYER, T.J. HATTON AND K. O'ROURKE}

Table 11.3 Counterfactual growth rates of wages and income, Ireland, 1858-1908

\begin{tabular}{|c|c|c|c|c|c|}
\hline & \multirow{3}{*}{ Actual } & \multicolumn{4}{|c|}{ Counter)'•actual } \\
\hline & & \multicolumn{2}{|c|}{ Capital immobile } & \multicolumn{2}{|c|}{ Capital mobile } \\
\hline & & Lower & Upper & Lower & Upper \\
\hline Labor force & -0.59 & 0.20 & 1.01 & 0.20 & 1.01 \\
\hline Agricultural real & & & & & \\
\hline wage & 1.07 & 0.73 & 0.39 & 0.96 & 0.84 \\
\hline Non-agricultural real & & & & & \\
\hline wage & 1.60 & 1.19 & 0.78 & 1.49 & 1.37 \\
\hline GNP & 0.70 & 1.21 & 1.71 & 1.40 & 2.11 \\
\hline GNP per capita & 1.29 & 1.01 & 0.70 & 1.20 & 1.10 \\
\hline
\end{tabular}

Table 11.4 Counterfactual changes in real wage ratios, Ireland, 1858-1908

\section{Counterfactual}

\begin{tabular}{|c|c|c|c|c|c|}
\hline & \multirow{3}{*}{ Actual } & \multicolumn{4}{|c|}{ Counterfactual } \\
\hline & & \multicolumn{2}{|c|}{ Capital immobile } & \multicolumn{2}{|c|}{ Capital mobile } \\
\hline & & Lower & Upper & Lower & Upper \\
\hline \multicolumn{6}{|l|}{ Ireland/GB } \\
\hline $\begin{array}{l}\text { Agricultural real } \\
\text { wage }\end{array}$ & 0.14 & 0.02 & -0.07 & 0.10 & 0.06 \\
\hline $\begin{array}{l}\text { Non-agricultural real } \\
\text { wage }\end{array}$ & 0.15 & 0.01 & -0.10 & 0.11 & 0.07 \\
\hline \multicolumn{6}{|l|}{ Ireland/US } \\
\hline $\begin{array}{l}\text { Agricultural real } \\
\text { wage }\end{array}$ & -0.10 & -0.23 & -0.34 & -0.13 & -0.17 \\
\hline $\begin{array}{l}\text { Non-agricultural real } \\
\text { wage }\end{array}$ & 0.15 & 0.01 & -0.10 & 0.11 & 0.07 \\
\hline
\end{tabular}

the unskilled building wage to represent the non-agricultural wage. ${ }^{10}$ Not surprisingly, in the case where capital is immobile there are sharp declines in the rates of real wage growth, in the upper estimate reducing agricultural wage growth from 1.1 percent per annum to only 0.4 percent. However, with mobile capital the rate of growth of agricultural wages only would have declined by about a quarter and the non-agricultural wage by less than a fifth.

For the growth of GNP, we assume a benchmark of 0.7 percent per annum based on 0 Grada's estimate for the period from 1845. The counterfactual estimates suggest that the growth rate would have been a little less than double the actual on the lowest estimate and about three times the actual on the highest estimate. GNP per capita growth would have fallen by a little less than a quarter on the lowest estimate and by only 7 percent in the case with the lower emigration effect and mobile capital.

Finally, in Table 11.4 we examine the effects of the alternative growth rates 
of real wages on the real wage ratios between Ireland and Great Britain and Ireland and the United States respectively. With immobile capital, the Irish/ British real wage ratio would have remained constant or declined from 1858 to 1908 . With capital mobile, there was still room for some gains in relative real wages, although the higher emigration estimate suggests that the gain over the whole 50-year period would have been cut by more than half. Each counterfactual estimate suggests that the Irish/US real agricultural wage ratio would have fallen by more than the actual 10 point decline. ${ }^{11}$ The Irish/US non-agricultural wage ratio would have still increased slightly except in the case of the high estimate with immobile capital.

The results can be compared with those obtained by O'Rourke, Williamson and Hatton in Chapter 10, using general equilibrium models for both the USA and Britain. These suggest that if there had been no emigration from Britain from 1871 to 1911 the unskilled urban wage would have been 12.2 percent lower if capital was immobile and 6.6 percent lower with capital mobile. Applying the same approach to the United States (no immigration from 1870 to 1910) indicates that American wages would have been higher by 34.0 and 9.2 percent respectively. Thus, allowing for the impact of migrations on these two countries would strengthen the Irish real wage convergence on the United States as a result of migration but weaken it against Britain.

\section{O N C L U S I O N}

During the period 1850-1913 Irish real wages and per capita income increased aj a rate that was quite respectable compared to wage and income growth in Great Britain and the United States. The Irish/British unskilled real wage ratio increased sharply, while the skilled real wage ratio remained roughly constant at 0.90 throughout the period. Irish/United States skilled and unskilled wage ratios increased from the early 1870 s to the mid 1890s, then declined somewhat to 1913. The increase in Irish living standards took place despite very slow industrialization.

This chapter has attempted to determine the extent to which Ireland's strong wage performance was a result of its unparalleled emigration rates. From 1851 to 1911 the Irish population declined by 25 percent. We estimate that, in the absence of emigration, the Irish population and labor force in 1911 would have been in a range between the 1851 level and 50 percent greater than the 1851 level.

We construct a computable general equilibrium model of the Irish economy in 1908, and use it to examine the effects of increasing the population and labor force by an amount which reflects the no-emigration counterfactual. Our results indicate that real wages and per capita income would have been lower in 1908 in the absence of emigration. The magnitude of the decline is strongly affected by our assumptions about international 


\section{G.R. BOYER, T.J. HATTON AND K. O'ROURKE}

capital mobility. If capital was completely immobile, we estimate that the real unskilled urban wage would have been 66-81 percent of its actual 1908 level, and per capita income 75-87 percent of its actual level. If capital was internationally mobile, the unskilled urban wage would have been 89-94 percent of its actual 1908 level, and per capita income 91-5 percent of its actual level. The estimates imply that emigration could have accounted for a significant amount of Ireland's real wage gain relative to Britain and for all of the gain relative to the United States.

\section{NOTES}

;" We have benefited from many useful comments from participants at the conference on Real Wages, Migration and International Labor Market Integration in the Nineteenth and Twentieth Centuries, Bellagio, Italy, 14-18 June, and especially from Jeff Williamson. Cormac O Grada and Andy Bielenberg provided valuable help with the data for the CGE model. In addition we are grateful to Theo Charitidis and Owen Darbishire for research assistance. Financial support from the National Science Foundation (Grant no. SES9021951) and from the Royal Irish Academy for Economics and Social Sciences is gratefully acknowledged.

1 For comparison with a larger set of countries and over a longer period of time see Williamson (1994).

2 The agricultural price index is taken from Turner (1987: 135-6).

3 For discussions of agricultural output and its composition, see Staehle (1950-1), Crotty (1966), and O Grada (1988).

46 Grada (1988: Ch. 4) points to the diffusion of a number of innovations including the use of new potato varieties, crop spraying, the diffusion of the milk separator, and towards the end of the period, the introduction of mechanization in the form of threshers and tractors. He estimates that between 1854 and 1908 total factor productivity in agriculture grew by 34 percent, or about half of 1 percent per annum.

5 An alternative method of estimating the counterfactual population and labor force would be to work from the stock of emigrants reported above. Such methods have been used by Williamson (1990: Ch. 6) to measure the labor force impact of Irish emigration to Britain, and in Chapter 10 by O'Rourke, Williamson and Hatton to estimate the impact of immigration to the United States and emigration from the United Kingdom.

6 The vital rates used for this simulation were taken from Mitchell and Deane (1962: 32-3, 36-7). Prior to the beginning of civil registration in 1864, the birth rate was assumed to be 26.7 per thousand and the death rate 16.9 per thousand.

7 Using different methods to calculate the impact of the Irish on the labor force in Britain, Williamson (1990: 143) estimates that between 1821 and 1871 the Irish-born population grew at 2.9 percent per annum, the total Irish population grew at 2.8 percent per annum, and the Irish labor force by 3 percent per annum. Similarly, 0 Grada and Walsh (1993: 27) report that simulations of different rates of emigration for present-day Ireland have little effect on the age structure of the population in the long run.

8 This assumption would evidently have been preferred by the Irish Commission on Population who observed: "Irish capital formed part of the world market and Irish industrial projects had to compete for capital with the opportunities for 


\section{EMIGRATION \& REAL WAGES IN IRELAND 1850-1914}

investment, not only in Great Britain but throughout the world that were freely offered to the investor" (1954: 26).

9 Two assumptions in particular were examined. First, the elasticity of substitution between Irish and foreign manufactured goods was reduced from 10 to 2 . With capital mobile, this gave a fall of 12 percent in the agricultural real wage on the upper estimate compared with the 11 percent in Table 11.2. Second, we tried an alternative estimate of industrial output in 1907 which is 25 percent lower (see Boyer, Hatton and O'Rourke, 1993, Appendix 3). With mobile capital, this gave a fall in the agricultural wage of 6 percent compared to the 11 percent estimate in Table 11.2.

10 For the building laborers' wage growth we take the 1860 real wage as representing 1858 .

11 We only have an estimate of the agricultural wage for the United States back to 1870. The figure for the growth rate of the agricultural wage was obtained by extrapolating the real agricultural wage back to 1858 using the non-agricultural unskilled wage. 